\title{
ANOECTOCHILUS NARASIMHANII (ORCHIDACEAE), A NEW 'JEWEL ORCHID' FROM THE ANDAMAN ISLANDS, INDIA
}

\author{
R. SUMATHI, J. JAYANTHI, K. KARTHIGEYAN \& P.V. SREEKUMAR \\ Botanical Survey of India, A \& N Circle, Port Blair - 744 102, India
}

\begin{abstract}
SUMMARY
A new species, Anoectochilus narasimhanii, allied to A. nicobaricus N.P. Balakr. \& Chakr. from Saddle Peak National Park in North Andamans is described and illustrated. It is the first record of the genus from the Andamans. It grows on humus rich soil, in the shade of stunted evergreen vegetation at an elevation of $\pm 650 \mathrm{~m}$.
\end{abstract}

Key words: Anoectochilus narasimhanii, Orchidaceae, North Andamans, India.

\section{INTRODUCTION}

The generic name Anoectochilus Blume is derived from the Greek words 'anoektos' (open) and 'chilos' (lip) referring to the shape of the lip. The genus belongs to the subfamily Neottioideae of the tribe Neottieae (Seidenfaden \& Wood, 1992). The genus Anoectochilus consists of over 35 species (Mabberley, 1998) distributed from tropical Asia to Western Pacific. About 16 species occur in India of which 7 are endemic (Sathish Kumar \& Manilal, 1994). In the Andaman and Nicobar Islands a single species has been described from Great Nicobar namely A. nicobaricus (Balakrishnan \& Chakraborty, 1978).

Anoectochilus belongs to the group of 'Jewel Orchids' with pretty dark purple-brown coloured velvety leaves, veined in gold. It has a remarkable horticultural significance because of its beautiful foliage and flowers. While inventorying the flora of Saddle Peak National Park in North Andamans, a species of Anoectochilus was collected which is allied to A. nicobaricus but remarkably different from it. A detailed description and illustration follows here.

Anoectochilus narasimhanii Sumathi, Jayanthi, Karthigeyan \& Sreek., spec. nov. - Fig. 1

Anoectochilo albolineato et A. nicobarico similis, a primo in columnae alis latioribus apicaliter sub stigmatis lobos triangularibus, a secundo in labelli ungue filamentis longioribus, epichilio lobulis angustioribus oblique cuneatis, calcare conico differt. - Typus: Sumathi, Jayanthi \& Karthigeyan 17368 (holo CAL; iso D, PBL), India, North Andamans, Saddle Peak National Park, 20 Sept. 2001.

Terrestrial herbs, 15-25 cm long, decumbent and rooting at nodes, leafy part of the stem up to $5 \mathrm{~cm}$ long. Leaves 3-5; petiole with sheaths $1-1.3 \mathrm{~cm}$ long; sheaths $6-7$ 


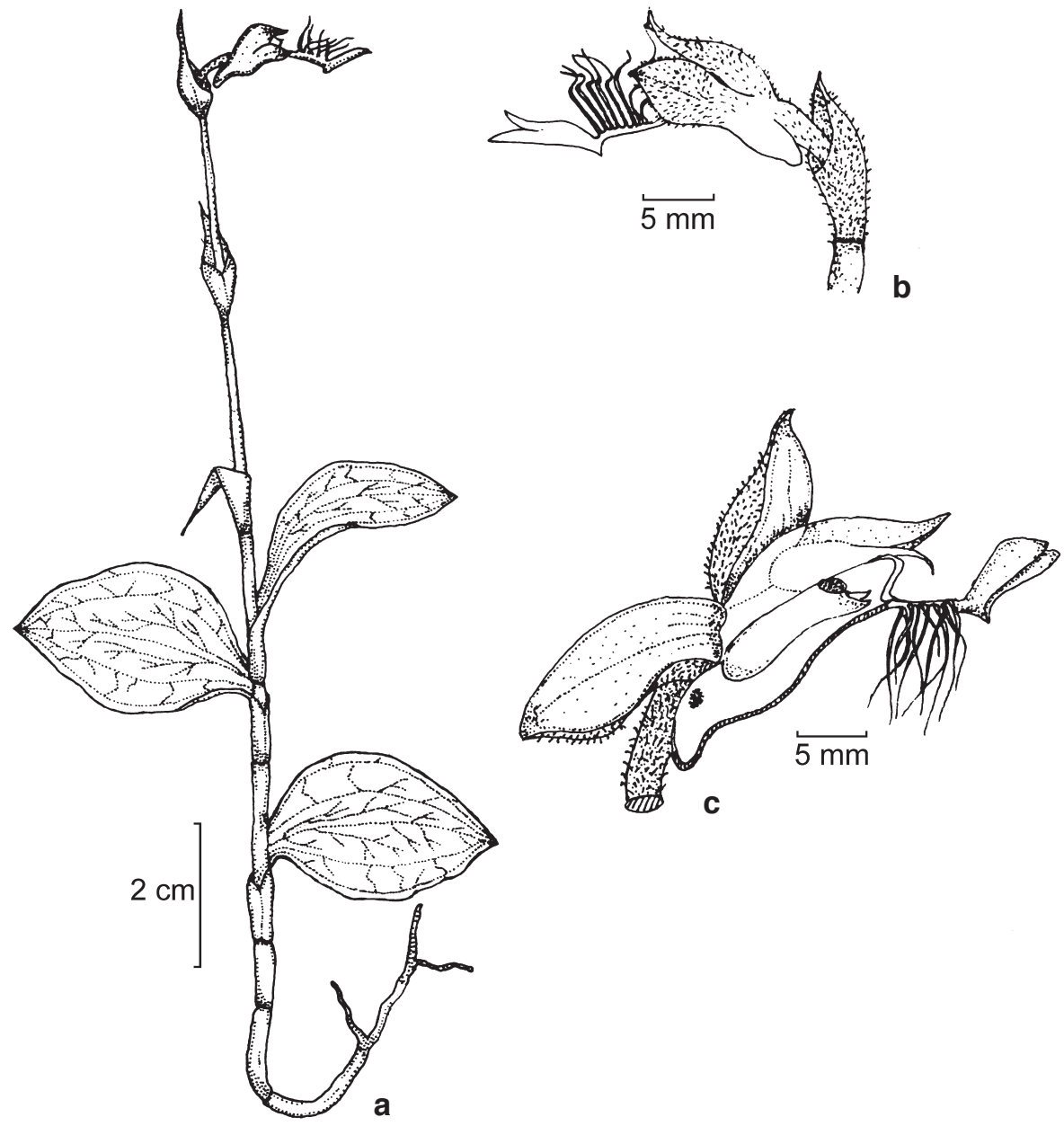

Fig. 1. Anoectochilus narasimhanii Sumathi, Jayanthi, Karthigeyan \& Sreek. a. Habit; b. flower; c. flower, longitudinal section (all: Sumathi, Jayanthi \& Karthigeyan 17368).

$\mathrm{mm}$ long, saccate, glabrous; lamina ovate-elliptic, $2-4.5$ by $1.5-2.5 \mathrm{~cm}$, obliquely rounded at base, entire at margins, acute at apex, dark purplish brown, velvety, with golden reticulate venation above, dark brownish beneath, 5-nerved, converging at the apex. Inflorescence 1-4-flowered, solitary, terminal; scape 6-9 cm long, axis densely villous; sterile bracts 2 or 3 , reddish brown, ovate-lanceolate, 1.5 by $1 \mathrm{~cm}$, sheathing at base, caudate at apex; fertile bracts reddish brown, ovate-lanceolate, 1.3 by $0.5 \mathrm{~cm}$, caudate at apex, keeled, villous outside, glabrous inside. Flowers $2 \mathrm{~cm}$ long. Ovary with pedicel c. $1 \mathrm{~cm}$ long, creamy green, villous. Dorsal sepal creamy green, ovate, 11-11.5 by $7-8 \mathrm{~mm}$, hyaline along the margin, keeled; lateral sepals creamy green with reddish tinge at apex and along the keel, lanceolate, 11-12 by 3-4 mm, villous outside, glabrous inside. Dorsal petals white, falcate, oblong, 11 by $4 \mathrm{~mm}$, acute at apex, 2-veined and adnate to dorsal sepal for about half of its length, forming a hood over the column; 
labellum $1.8 \mathrm{~cm}$ long with 2 calli at base; hypochile 5 by $5 \mathrm{~mm}$; mesochile (claw) $4 \mathrm{~mm}$ long with 8 slender, $7 \mathrm{~mm}$ long threads on either side; epichile lobules obliquely cuneate, 5 by $1.5-2 \mathrm{~mm}$, obtuse truncate at apex. Spur conical, $6 \mathrm{~mm}$ long, apex facing the dorsal side. Column up to $9 \mathrm{~mm}$ long; column wings $2.75 \mathrm{~mm}$ long, triangular below stigma lobes, projecting halfway into spur. Rostellum 2-fid with 2 stigma lobes on either side. Pollinia clavate, $5 \mathrm{~mm}$ long, divided into numerous lobules.

Distribution - India: Andaman Islands.

Habitat \& Ecology - Stunted evergreen forest; altitude $\pm 650 \mathrm{~m}$. Flowering: August to November. Grows concealed on leaf litter in stunted evergreen vegetation in association with Sonerila melastomatoides L.

Etymology - This species is named in honour of our teacher Dr. D. Narasimhan, an eminent South Indian taxonomist, who inspired us to learn taxonomy.

Notes - This new species is closely allied to Anoectochilus nicobaricus and A. albolineatus Parish \& Rchb.f. but differs from both in the following aspects: It differs from $A$. nicobaricus in having a lip with longer threads, a spur that is conical at apex unlike A. nicobaricus which has an ellipsoid-oblongoid spur, and an epichile that has narrower obliquely cuneate lobules. In A. narasimhanii the column wings are broader and apically triangular below the stigma lobes, whereas in A. albolineatus the column wings are truncate and cut off at the apex below the stigma lobes.

This remarkable species could be grown as an ornamental because of its beautiful foliage and flower.

\section{ACKNOWLEDGEMENTS}

We are grateful to Dr. M. Sanjappa, Director BSI, for facilities, Dr. P.G. Diwakar, Deputy Director BSI, ANC, for encouragement, Dr. Paul Ormerod for confirming the identity of the species, Dr. P. Dayanandan and Dr. C. Livingstone, Madras Christian College, for encouragement, and to Dr. J.F. Veldkamp, Nationaal Herbarium Nederland, Universiteit Leiden branch, for the Latin diagnosis.

\section{REFERENCES}

Balakrishnan, N.P. \& P. Chakraborty. 1978. Descriptive note on some new or little known orchids of Nicobar Islands. Bull. Bot. Surv. India 20: 80-90.

Mabberley, D.J. 1998. The Plant-book, 2nd ed. Cambridge University Press, Cambridge.

Sathish Kumar, C. \& K.S. Manilal. 1994. A catalogue of Indian orchids. Bishen Singh Mahendra Pal Singh, Dehra Dun.

Seidenfaden, G. \& J.J. Wood. 1992. The orchids of Peninsular Malaysia and Singapore. Olsen \& Olsen, Fredensborg. 